\title{
ANALISIS KRITIS TERHADAP GERAKAN NASIONAL LITERASI DIGITAL DALAM PERSPEKTIF GOOD GOVERNANCE
}

\author{
Dadan Kurnia \\ Ilmu Pemerintahan, Fakultas Ilmu Sosial dan Ilmu Politik \\ Universitas Jenderal Achmad Yani
}

\begin{abstract}
Abstrak
Tulisan ini hendak menganalisis Gerakan Nasional Literasi Digital (GNLD) dari perspektif Good Governance dengan metode kualitatif. Analisis ini dilatarbelakangi oleh pro dan kontra terhadap GNLD. Pihak yang pro memandang gerakan ini bagus untuk melawan hoaks, berita palsu, berita bohong maupun konten-konten negatif lainnya yang beredar di masyarakat luas. Sementara yang kontra menilai, gerakan ini sebagai upaya pemerintah untuk menggiring opini publik untuk melegitimasi dan membungkam suara-suara yang mengkritik kebijakan pemerintah. Simpulan analisis GNLD dalam perspektif good governance bahwa GNLD merupakan upaya pemerintah untuk memberikan layanan keamanan sekaligus memberdayakan masyarakat dalam berselancar di dunia maya.
\end{abstract}

Kata Kunci: Analisis kritis, gerakan nasional literasi digital, good governance

\begin{abstract}
This paper intends to analyze the National Digital Literacy Movement (GNLD) from the perspective of good governance with qualitative methods. This analysis is motivated by the pros and cons of GNLD. Those who are pro view this movement as good for fighting hoaxes, fake news, fake news and other negative content circulating in the wider community. Meanwhile, those who argue that this movement is an attempt by the government to lead public opinion to legitimize and silence voices criticizing government policies. The conclusion of the GNLD analysis from the perspective of good governance is that GNLD is a government effort to provide security services while empowering people to surf in cyberspace.
\end{abstract}

Keywords: critical analysis, digital literacy national movement, good governance

\section{PENDAHULUAN}

"Maha benar netizen dengan segala komentarnya". Kalimat satir ini seolah menggambarkan bagaimana netizen -- sebutan untuk masyarakat dunia maya -menjadi pemilik 'kebenaran', dan siapapun yang bertentangan dengan mereka akan 
habis dibullying, dihujat, dicemooh, dihina tanpa adab sedikitpun. Dan ironisnya mereka melakukan itu dengan penuh kesenangan dan tanpa rasa bersalah.

Joel Stein (2016) dalam artikelnya di majalah Time yang berjudul "Why We're Losing the Internet to a Culture of Hate," menyebut internet telah menjadi Tyranny of the mob sebuah ajang yang mempertemukan agresivitas dan kekerasan. Stein menyebut kehadiran internet yang awalnya ditujukan untuk mempermudah akses informasi dan komunikasi para kutu buku, kini telah dimasuki orang-orang yang anti sosial, tidak peduli terhadap lingkungannya, senang mengolok-olok orang, menghina dan menebar kebencian. Stein menyebut, fenomena Troll yang merasuki dunia internet telah menjadikan internet sebagai monster yang menakutkan, Internet trolls have a manifesto of sorts, which states they are doing it for the "lulz," or laughs. What trolls do for the lulz ranges from clever pranks to harassment to violent threats ${ }^{\text {. }}$.

Trolls merupakan tindakan (negatif) yang dilakukan masyarakat melalui jejaring internet, seperti menghina, membuat lelucon, melakukan pelecehan. Beberapa merekam dirinya sendiri dan berkomentar sangat kasar. Beberapa yang demikian jahat mempublikasikan data pribadi seperti rekening bank atau bahkan foto $\mathrm{KTP}^{2}$

Masih ingat video prank membagikan bingkisan sembako yang ternyata berisi sampah dan batu yang dibuat youtuber Ferdian Paleka dan dua orang rekannya pada Mei 2020 lalu tidak hanya membuat korban merasa terhina dan dilecehkan, tetapi juga membuat geram masyarakat luas bahkan massa menggeruduk rumah Ferdian yang disebutkan di Kavling Bojong Koneng Indah, Kecamatan Baleendah, Kabupaten Bandung. ${ }^{3}$

Tidak hanya sekedar lucu-lucuan, internet yang menjadi sarana lahirnya media sosial, menjadi sarana menebar hoax, berita bohong atau palsu, menebarkan kebencian dan permusuhan yang berakibat fatal. Terbaru adalah kasus perusakan Kantor Polsek Pasar Rebo dan Pasar Ciracas Jakarta Timur pada Sabtu 29 Agustus

\footnotetext{
${ }^{1}$ https://time.com/4457110/internet-trolls/, diakses pada 28 Agustus 2020

${ }^{2}$ https://tirto.id/bullying-dan-penindasan-di-media-sosial-bVZj, diakses 27 Agustus 2020

${ }^{3} \mathrm{https}$ ://radarsukabumi.com/berita-utama/youtuber-ferdian-paleka-bikin-ulah-ke-waria-rumahnyadikepung-warga/, diakses pada 28 Agustus 2020
} 
2020 lalu oleh sekitar 100 orang oknum anggota TNI AD yang terprovokasi berita hoax.

Panglima TNI Marsekal Hadi Tjahjanto mengatakan aksi perusakan tersebut bermula dari kabar bohong yang disebarkan Prada MI. Awalnya MI mengaku dikeroyok oleh orang tidak dikenal dan menyebabkan luka-luka. Kemudian MI menghubungi 27 rekannya dan berkembang kabar bohong tersebut hingga akhirnya terjadi aksi perusakan di wilayah Pasar Rebo dan Ciracas. ${ }^{4}$

Sebelumnya, jelang akhir tahun 2019, wilayah Timur Indonesia memanas. Kerusuhan pecah di Kota Wamena, Papua. Aksi unjuk rasa kelompok siswa berujung anarkis, pada Senin (23/9). Dugaan awal, kerusuhan terjadi akibat penyebaran berita hoax bernada rasisme.

Kepala Biro Penerangan Masyarakat (Karopenmas) Divisi Humas Mabes Polri saat itu Brigjen Pol Dedi Prasetyo tidak menjelaskan detail konten rasisme tersebut. Aparat sendiri masih melakukan pengejaran kepada pelaku penyebar kabar bohong itu. "Hoaxnya tentang rasis, tetap. Penyebar hoaxnya sedang didalami oleh Ditsiber Bareskrim," tegasnya. ${ }^{5}$

Temuan Kementerian Komunikasi dan Informatika mengungkapkan terdapat dua hoaks yang beredar di tanah Papua dan memicu kerusuhan. Hoaks pertama berjudul "Foto Mahasiswa Papua Tewas Dipukul Aparat di Surabaya." Hoaks ini berisi foto dan informasi adanya seorang mahasiswa Papua di Surabaya yang meninggal dunia akibat dipukul aparat TNI-Polri.

"Mabes Polri melalui akun media sosial Divisi Humas Polri memberikan klarifikasi. Menurut Polri, foto itu hoaks. Mereka menjelaskan bahwa foto tersebut adalah foto korban kecelakaan lalu lintas yang meninggal di TKP laka lantas, di Jalan Trikora. Tepatnya di depan TK Paut DOK V Atas Distrik Jayapura Utara, Selasa (19/2) pukul 07.30 WIT."

Hoaks kedua berjudul "Polres Surabaya menculik Dua Orang Pengantar Makanan untuk Mahasiswa Papua". Hoaks berjenis disinformasi ini berisi kabar

\footnotetext{
${ }^{4} \mathrm{https} / / / \mathrm{m}$. detik.com/news/berita/d-5152474/pernyataan-lengkap-panglima-tni-terkait-hoax-picuperusakan-polsek-ciracas, diakses tanggal 31 Agustus 2020

${ }^{5}$ https://www.jawapos.com/nasional/28/12/2019/kaleidoskop-2019-karena-berita-hoax-kerusuhanwamena-pecah/, diakses 30 Agustus 2020
} 
adanya penculikan dua orang mahasiswa yang ditangkap hanya karena mengantarkan makanan untuk penghuni asrama mahasiswa Papua yang dikepung yang oleh Polres Surabaya.

Kasat Intel Polrestabes Surabaya AKBP Asmoro membantah terjadinya penculikan. Ia menjelaskan, kepolisian hanya mewawancarai dan memeriksa kedua orang tersebut. Dua hoaks ini beredar ketika kerusuhan terjadi dan menambah panas situasi lantaran berita bohong tersebut. ${ }^{6}$

Sejumlah studi menemukan, ketika hoaks dicerna otak, hal ini akan terus memengaruhi keyakinan dan tindakan manusia. Otak tidak memiliki mekanisme yang memungkinkan manusia menghapus suatu kabar.

Sementara itu, sejumlah penelitian telah membuktikan bahwa ada bias konfirmasi antara kabar hoaks dan bukan. Bukti-bukti ilmiah pun telah merangkul bias konfirmasi berita untuk mencerminkan kekuatan prasangka di masyarakat. Terlebih, sebagian besar manusia berasumsi, apa yang kita dengar itulah yang benar. Sebuah studi mengatakan, banyak informasi salah tersebar di media sosial seperti Facebook.

Ahli menemukan, teori konspirasi dan hoaks mudah tersebar karena manusia cenderung memilih dan membagikan ulasan berdasarkan narasi yang sudah terbentuk sebelumnya. Selain itu, manusia cenderung bergaul dengan orangorang yang berpikiran dan memiliki kepentingan sama. Inilah yang makin membuat kabar bohong menggema. ${ }^{7}$

Kejadian-kejadian di atas hanya beberapa kasus yang terangkat ke publik. Tidak sedikit kasus akibat berita bohong, kebencian, rasis, penghinaan, perundungan hingga pelecehan menyebabkan hancurnya kehidupan seseorang, disharmoni sosial, konflik sosial hingga disintegrasi bangsa. Seperti keresahan Stein yang mempertanyakan mengapa masyarakat modern tunduk pada budaya kebencian di internet. Alih-alih memajukan dan menjadi sarana bertukar informasi yang sehat, internet khususnya media sosial, menjadi tempat untuk saling menghina

\footnotetext{
${ }^{6} \mathrm{https}: / / \mathrm{m} . c n n i n d o n e s i a . c o m / t e k n o l o g i / 20190819203042-185-422838 /$ kominfo-ungkap-temuanhoaks-saat-rusuh-papua, diakses 30 Agustus 2020

${ }^{7}$ https://sains.kompas.com/read/2019/09/24/170300323/kerusuhan-wamena-kenapa-kemarahankarena-hoaks-bisa-sangat-merusak-?page=all, diakses 30 Agustus 2020
} 
dan menghancurkan hidup orang lain. Ia menyebut internet telah menjadi tempat bagi seseorang menjadi monster dan menghancurkan hidup orang lain hanya untuk bersenang-senang.

Menyikapi kondisi tersebut pemerintah Indonesia telah menerbitkan berbagai peraturan perundangan untuk melakukan penertiban, diantaranya UndangUndang Nomor 11 Tahun 2008 tentang Informasi dan Transaksi Elektronik sebagaimana telah diubah dengan Undang-Undang Nomor 19 Tahun 2016 tentang Perubahan Atas Undang-Undang Nomor 11 Tahun 2008 tentang Informasi dan Transaksi Elektronik; Peraturan Pemerintah Nomor 71 Tahun 2019 tentang Penyelenggaraan Sistem dan Transaksi Elektronik; Peraturan Mentri Komunikasi dan Informatika Nomor 20 Tahun 2016 Tentang Perlindungan Data Pribadi Dalam Sistem Elektronik, dan berbagai peraturan lainnya.

Inti dari diterbitkannya berbagai peraturan dan perundangan adalah untuk melindungi para pengguna internet dari berbagai tindak kejahatan siber. Sehingga dampak negatif penggunaan internet dapat diminimalisir, dan keberadaannya dapat dioptimalkan secara positif untuk kemajuan bersama.

Namun faktanya, keberadaan aturan tersebut tidak banyak membantu pemerintah dalam melindungi masyarakatnya. Sepanjang Maret 2019 Kementerian Komunikasi dan Informatika (Kominfo) berhasil mengidentifikasi 453 hoaks, kabar bohong, dan berita palsu. Dari 453 hoaks tersebut, 130 di antaranya merupakan hoaks politik. Hoaks politik yang kerap muncul antara lain berupa kabar bohong yang menyerang pasangan calon presiden dan wakil presiden, partai politik peserta pemilu maupun penyelenggara pemilu.

Selain menerbitkan berbagai peraturan dan perundangan untuk menertibkan para pengguna internet, pemerintah juga berupaya untuk meningkatkan dan memberdayakan masyarakat dengan mengeluarkan kebijakan berinternet sehat melalui Gerakan Nasional Literasi Digital \#SiBerkreasi pada Oktober 2017 lalu.

Dalam siaran persnya pada 2 Oktober 2017 kehadiran Gerakan Nasional Literasi Digital \#SiBerkreasi dilatari kegelisahan berbagai elemen masyarakat terhadap besarnya ancaman potensi bahaya penyebaran konten negatif di dunia maya. Gerakan \#SiBerkreasi merupakan kolaborasi berbagai institusi pemerintah 
maupun swasta, komunitas dan pegiat literasi digital. Gerakan ini merupakan bagian dari komitmen bersama berbagai pihak untuk meningkatkan literasi digital di masyarakat lewat ajakan untuk berbagi kreativitas lewat konten positif dan memanfaatkan internet secara bijak dan bertanggungjawab.

Menurut Menteri Komunikasi dan Informatika Rudiantara pemerintah memiliki kewajiban dalam upaya pencegahan penyebarluasan dan penggunaan Informasi dan/atau Dokumen Elektronik yang memiliki muatan yang dilarang sesuai ketentuan Peraturan perundang-undangan. Untuk itu dalam pelaksanaannya, dilakukan dua sisi pendekatan yaitu pertama, Pengendalian Sosial dan Budaya dengan mendorong masyarakat semakin sadar dan memahami adanya konten negatif dan diberikan pemahaman dan cara bagaimana memperlakukan konten negatif melalui sosialisasi dan literasi oleh berbagai pihak baik oleh kalangan dari pemerintah, kalangan dari tokoh masyarakat dan kalangan dari para penggiat di masyarakat baik asosiasi, gerakan ataupun LSM. Dengan demikian diharapkan masyarakat tahu dan bisa memilah informasi yang diterima.

Kedua, Pengendalian melalui Sarana Teknologi Informasi dengan cara melakukan pemblokiran, penutupan atau penghapusan konten yang memang berpotensi tidak sesuai dengan norma luhur bangsa Indonesia, dinilai dapat menimbulkan konflik di mayarakat dan konten negatif lainnya berkenaan dengan perundang-undangan. Tindakan kedua ini juga sangat membutuhkan partisipasi masyarakat dan juga berbagai lembaga melalui pengaduan konten negatif. Pendekatan pengendalian secara teknologi ini sangat erat dengan koordinasi dengan penyelenggara jasa akses Internet (ISP) dan penyedia layanan aplikasi/konten.

Dalam konteks good governance kebijakan Gerakan Nasional Literasi Digital \#SiBerkreasi merupakan salah satu layanan yang dilakukan pemerintah kepada masyarakat maupun kalangan swasta dalam upaya melindungi dari berbagai kejahatan digital maupun konten-konten negatif yang dapat merugikan masyarakat secara umum, bangsa dan negara. Dan dalam pelaksanaannya dilakukan secara bersama dengan merangkul selutuh stakeholder terkait untuk melawan penyebaran konten negatif diinternet dengan menyebarkan konten-konten positif, memilah dan memilih informasi sebelum dibagikan hingga penegakan hukum. 
Persoalannya, setelah dua tahun lebih sejak peluncurannya, Gerakan Nasional Literasi Digital \#SiBerkreasi menuai pro dan kontra. Sebagian pihak pro terhadap gerakan ini menilai GNLD merupakan upaya pemerintah untuk melindungi dan memberikan rasa aman kepada masyarakat terhadap berbagai ancaman yang ditimbulkan akibat perkembangan teknologi informasi dan komunikasi. Gerakan yang melibatkan 108 lembaga (pemerintah dan swasta), kelompok masyarakat dan komunitas juga memberdayakan masyarakat dengan memberikan edukasi maupun pelatihan dalam berinteraksi di internet dan dapat menghasilkan berbagai konten positif serta menyebarkan kebaikan kepada masyarakat luas.

Tidak hanya memperoleh dukungan luas masyarakat, GNLD Siberkreasi juga memperoleh apresiasi dikancah internasional dengan mendapat penghargaan dari Perserikatan Bangsa Bangsa (PBB) berupa World Summit on the Information Society (WSIS Prize) 2020. Bahkan Relawan TIK yang merupakan network society dari GNLD juga berhasil menyabet gelar champion di forum lintas-pemangku kepentingan di bidang TIK di bawah naungan International Telecommunication Union (ITU) PBB. Relawan TIK merupakan komunitas yang terdiri dari 8.000 relawan yang bertugas untuk membantu pemerintah dalam mensosialisasikan program yang berkaitan dengan penggunaan internet, sekaligus pemberdayaan kepada masyarakat melalui informasi, edukasi sosial, teknologi, dan komunikasi. ${ }^{8}$

Kendati mendapat apresiasi dikancah intrnasional, tidak sedikit pihak yang menilai GNLD Siberkreasi untuk melatih influencer. Tudingan itu berawal dari pernyataan Staf Ahli Menkominfo Henry Subiakto. Ia menyeret soal Siberkreasi, yang salah satunya membahas pelatihan kepada masyarakat untuk menjadi influencer. Pernyataan tersebut kemudian viral di media sosial. Kemudian beragam tudingan muncul terhadap Siberkreasi, dari disebut organisasi buzzer/influencer, hingga serangan terhadap Ketua Umumnya, Yosi Mokalu alias Yosi Project Pop. ${ }^{9}$

\footnotetext{
${ }^{8}$ https://beritacenter.com/news-268835-sempat-dituding-organisasi-buzzer-siberkreasi-kominforaih-prestasi-di-kancah-internasional.html

${ }^{9} \mathrm{https}: / /$ channel9.id/siberkreasi-dituding-sebagai-organisasi-buzzer-berikut-penjelasan-kominfo/
} 
Ekonom senior Rizal Ramli dalam cuitannya di twitter miliknya @ ramlirizal memberikan tanggapan cukup pedas tergadap para buzzer/influencer ini, "Maaf, mereka mengikuti doktrin Herman Goebels ahli propaganda Hitler 'Jika kebohongan diulang terus menerus dan secara masid maka akan menjadi kebenaran'. Jika 10.000 buzzerRp termasuk bot melakukan tweet kebohongan 10x/hari, sebulan akan 3 juta tweets menghancurkan tokoh,"10

Bahkan Indonesia Corruption Watch (ICW) mengungkap temuan adanya penggunaan anggaran pemerintah pusat untuk influencer sebesar Rp90,45 miliar. Peneliti dari ICW Egi Primayogha mengungkapkan, data total anggaran belanja pemerintah pusat untuk aktivitas yang melibatkan influencer mencapai Rp90,45 miliar. Anggaran itu dikucurkan sejak 2017 hingga 2020. ${ }^{11}$

Kritik juga dilontarkan Direktur Eksekutif Lokataru Haris Azhar yang tidak rela dana rakyat dari APBN digelontorkan untuk para buzzer yang bekerja untuk menyerang aktivis demokrasi dan HAM, bahkan peyidik KPK seperti Novel Baswedan di media sosial.

"Saya keberatan uang rakyat dibuang-buang untuk membiayai kelompok ini (buzzer). Dicek teman-teman masyarakat sipil, follower akun-akun anonim penyerang itu cuma 3, 6," kata Haris dalam diskusi bertopik Riuh Keruh Media Sosial dan Kebebasan Berpendapat yang diselenggarakan Rekat Anak Bangsa, Sabtu (20/6/2020).

Haris menilai pemerintah kerap abai dalam menegakan hukum bagi warga negara yang membutuhkan keadilan. Namun ketika warga yang bersuara dan mengkritik pemerintah justru dikriminalisasi. Seperti kasus yang dialami Ravio Patra, pegiat demokrasi dan HAM, akun WhatsApp nya diretas karena terlalu lantang mengkritik kebijakan pemerintah dalam penanganan wabah.

"Negara sekarang perannya kebolak balik. Ketika harus intervensi seperti proses penegakan hukum kasus penyiraman air keras terhadap Novel Baswedan

\footnotetext{
${ }^{10} \mathrm{https}: / /$ www.suara.com/news/2020/06/08/172739/rizal-ramli-sebut-buzzer-jokowi-sampah-fadlizon-ikut-kasih-sindiran

${ }^{11} \mathrm{https} / / / \mathrm{www}$.oposisicerdas.com/2020/08/icw-temukan-anggaran-buzzer-rp-90-m.html
} 
negara tidak hadir. Tetapi ketika ada warga yang berjuang untuk keadilan, mengkritik malah negara mengintervensi," ujarnya. ${ }^{12}$

Pro kontra yang muncul seiring kebijakan Gerakan Nasional Literasi Digital (GNLD) Siberkreasi menjadi hal menarik untuk dicermati lebih jauh dari perspektif good governance. Permasalahan mendasar dalam gerakan ini adalah, apakah GNLD merupakan gerakan yang lahir daari inisiatif masyarakat yang dikelola bersama dengan pemerintah dan swasta? Atau sebaliknya, gerakan ini diinisiasi oleh pemerintah dengan melibatkan masyarakat dan swasta? Inisiasi menjadi penting maknanya manakala peran masing-masing pihak menjadi tidak berimbang. Dalam konteks good governance, kesetaraan menjadi salah satu kunci, seperti yang disebutkan O’Brien dalam Nugroho (2005:142) bahwa good governance adalah penjumlahan dari cara-cara dimana individu-individu dan institusi-institusi baik privat maupun publik mengelola urusan-urusan bersamanya.

Gerakan Literasi Digutal telah banyak dilakukan penelitian sebelumnya. Seperti penelitian yang dilakukan Novi Kurnia \& Santi Indra Astuti (2017) dengan judul Peta Gerakan Litefasi Digital di Indonesia : Studi Tentang Pelaku, Ragam Kegiatan, Kelompok Sasaran dan Mitra menyebutkan persoalan seperti informasi hoaks, pelanggaran privacy, cyberbullying, konten kekerasan dan pornografi, dan adiksi media digital dianggap sebagai persoalan masyarakat digital terkini. Temuan utama penelitian ini antara lain: perguruan tinggi adalah pelaku utama atau motor dalam gerakan literasi digital, sosialisasi adalah kegiatan yang paling sering dilakukan, kaum muda merupakan kelompok sasaran yang paling dominan, dan mitra yang paling adalah sekolah. Penelitian merekomendasikan perlunya lebih banyak pelaku kegiatan yang bukan berasal dari perguruan tinggi, pentingnya mengeksplorasi ragam literasi digital yang bersifat kreatif dan 'empowerment', perlunya memperluas target sasaran literasi digital supaya tidak hanya tertuju pada kaum muda saja, dan pentingnya kemitraan dengan berbagai pihak diperluas dan diperkuat, khususnya dengan pemerintah, media dan korporasi. Selain itu, peneliti

\footnotetext{
12 https://www.suara.com/news/2020/06/20/162716/pemerintah-dituding-hamburkan-uang-pajakrakyat-untuk-bayar-buzzer
} 
merekomendasikan bahwa literasi digital harus diberikan dalam level keluarga, sekolah, dan negara.

Penelitian kedua dilakukan Iko Aulya Prabandari Santoso, Syaiful Anwar, Surryanto Djoko Waluyo (2020) dengan judul Peran Siberkreasi Dalam Meningkatkan Kemampuan Literasi Digital Untuk Mencegah Aksi Radikalisme memberikan gambaran bahwa perkembangan teknologi digital memberikan beragam kemudahan baagi penyebaran paham-paham radikal. Oleh karenanya gerakan literasi digital sangat penting diberikan, terutama dikalangan generasi muda, untuk mencegah penyebaran paham radikal yang dapat berkembang menjafi aksi terorisme. Hasil penelitian ini menyimpulkan peran Siberkreasi dalam meningkatkan kemampuan literasi digital generasi muda di Indonesia perlu dioptimalkan dengan melakukan kajian lebih lanjut tentang program dan materi apa yang harus difokuskan dan ditingkatkan. Soft approach dalam mencegah ancaman radikalisme yang lebih efektif adalah kontra radikalisasi yang dilakukan melalui program pandu digital yang dimodifikasi sesuai dengan kebutuhan kontra radikalisasi untuk menghadapi aksi radikalisme digital.

Penelitian berikutnya dilakukan oleh Anindita Lintang Pakuningjati (2015) yang berjudul Pengelolaan Media Sosial dalam Mewujudkan Good Governance (Studi Kasus Pengelolaan Media Sosial LAPOR! sebagai Sarana Aspirasi dan Pengaduan Rakyat secara Online Oleh Deputi I Kantor Staf Presiden). Salah satu kesimpulannya menyebutkan bahwa dalam pengelolaan aplikasi LAPOR! Terdapat campur tangan pengelola terhadap pesan yang cukup besar. Pada tahapan pelaksanaan, LAPOR! melakukan suntingan terhadap aduan yang maksud. Suntingan yang dilakukan sebatas suntingan redaksional dan tata bahasa. Namun, peneliti menilai bahwa penyuntingan yang dilakukan ini rawan mengalami perubahan makna. Selain itu, langkah penyuntingan yang dilakukan LAPOR! tidak sejalan dengan karakter media sosial itu sendiri. Media sosial merujuk pada Saxena (2013) memiliki karakter konten yang user oriented tanpa adanya editor. Dengan kata lain, konten yang ada di media sosial tidak mengalami editing dan berasal dari pengguna media sosial itu sendiri. Pada LAPOR! konten yang ditampilkan adalah konten yang telah mengalami editing oleh administrator. Sehingga menurut peneliti 
LAPOR! bukanlah media sosial seutuhnya, tetapi sebuah layanan aduan dan aspirasi yang mengadopsi sistem media sosial.

Dalam artikel ini peneliti berupaya menganalisis Gerakan Nasional Literasi Digital daari perspektif good governance. Hal ini menarik sebab gerakan ini mendapat respon pro kontra di masyarakat. Di satu sisi, gerakan ini dinilai sebagai upaya pemerintah untuk melindungi, memberikan rasa aman sekaligus memberdayakan masyarakat melalui literasi digital. Namun disisi lain, gerakan ini dinilai sebagai upaya pemerintah untuk menggiring opini masyarakat untuk melegitimasi berbagai kebijakan pemerintah. Dalam konteks ini, ruang perbedaan pendapat maupun kritik menjadi kritis karena dianggap sebagai ancaman dan membahayakan. Mengutip hasil temuan Freedom House on the Net 2018 yang menyimpulkan bahwa terdapat gejala Digital Authoritarianism yang tidak hanya terjadi di Indonesia, tapi juga di seluruh dunia. Kondisi ini dibuktikan dengan upaya berbagai Pemerintah di seluruh dunia dalam memperketat kontrol atas data publik dan menggunakan klaim "berita palsu" untuk menekan perbedaan pendapat menurun dalam tahun kedelapan berturut-turut sejak $2010^{13}$

Good Governance sering diartikan sebagai tata pemerintahan yang baik. Menurut World Bank dalam Mardiasmo (2009:18) mendefinisikan good governance sebagai suatu penyelenggaraan manajemen pembangunan yang solid dan bertanggung jawab yang sejalan dengan prinsip demokrasi dan pasar yang efisien, penghindaran salah alokasi dana investasi, dan pencegahan korupsi baik secara politik maupun administratif menjalankan disiplin anggaran serta penciptaan legal dan political framework bagi tumbuhnya aktivitas usaha.

Sedangkan menurut United Nations Development Program (UNDP) dalam Mardiasmo (2009:18) mendefinisikan good governance sebagai praktik penerapan kewenangan pengelolaan berbagai urusan penyelenggaraan negara secara politik, ekonomi, dan administratif di semua tingkatan. Dalam konsep ini, good governance memiliki 3 pilar penting, yaitu: 1) Economic governance (kesejahteraan rakyat); 2)

\footnotetext{
${ }^{13}$ https://freedomhouse.org/report/freedom-net/freedom-net-2018
} 
Political governance (proses pengambilan keputusan); 3) Administrative governance (tata laksana pelaksanaan kebijakan)

Untuk memahami good governance diperlukan pemahaman atas prinsipprinsip yang terkandung di dalamnya. Hal ini berfungsi sebagai indikator atau tolak ukur kinerja pemerintah. Adapun prinsip-prinsip good governance menurut UNDP dalam Mardiasmo (2009:18) mengungkapkan bahwa karakteristik atau prinsipprinsip yang dikembangkan dalam pelaksanaan good governance meliputi :

1. Participation. Keterlibatan masyarakat dalam pembuatan keputusan baik secara langsung maupun tidak langsung melalui lembaga perwakilan yang dapat menyalurkan aspirasinya. Partisipasi tersebut dibangun atas dasar kebebasan berasosiasi dan berbicara serta berpartisipasi secara konstruktif.

2. Rule of law. Kerangka hukum yang adil dan dilaksanakan tanpa pandangan bulu.

3. Transparency. Transparansi dibangun atas dasar kebebasan memperoleh informasi. Informasi yang berkaitan dengan kepentingan publik secara langsung dapat diperoleh oleh mereka yang membutuhkan.

4. Responsiveness. Lembaga-lembaga publik harus cepat dan tanggap dalam melayani stakeholder.

5. Consensus orientation. Berorientasi pada kepentingan masyarakat yang lebih luas.

6. Equity. Setiap masyarakat memiliki kesempatan yang sama untuk memperoleh kesejahteraan dan keadilan.

7. Efficiency and Effectiveness. Pengelolaan sumber daya publik dilakukan secara bedaya guna (efisien) dan berhasil guna (efektif).

8. Accountability. Pertanggungjawaban kepada publik atas setiap aktivitas yang dilakukan.

9. Strategic vision. Penyelenggara pemerintah dan masyarakat harus memiliki visi jauh ke depan.

Menurut Mardiasmo (2009:18) dari sembilan karakteristik tersebut terdapat tiga pilar yang saling berkaitan untuk mewujudkan good governance yaitu transparansi, partisipasi, dan akuntabilitas, serta terdapat satu elemen lagi yang dapat mewujudkan good governance yaitu value for money (ekonomi, efisiensi, dan efektivitas).

Selanjutnya adalah pengertian dari literasi yang dimaknai literasi dimaknai sebagai kemampuan membaca dan menulis. Namun pada perkembangannya, kemampuan membaca dan menulis saja tidak cukup untuk membentuk masyarakat yang mampu menjalankan fungsi (sosialnya) dengan baik. Tidak sedikit orang 
memiliki kemampuan membaca dan menulis dengan baik, namun tidak mampu berinteraksi dan merespon dengan baik lingkungannya, anti sosial bahkan intoleran terhadap perbedaan. Untuk itu maka pemaknaan literasi pada gilirannya, tidak hanya diukur dari kemampuan baca dan tulis yang berhubungan dengan ilmu pengetahuan, tetapi juga berkaitan dengan dinamika kehidupan masyarakat. Oleh karenanya literasi berkembang sesuai konteksnya, seperti literasi politik, literasi informasi, literasi media, literasi finansial maupun literasi digital.

Awalnya literasi diartikan sebagai kemelek-hurufan. Namun hal tersebut menimbulkan banyak pertentangan sebab literasi hanya dibatasi pada kemampuan baca-tulis secara harfiah dan teknis. Padahal, dalam kehidupan masyarakat kemampuan membaca dan menulis lebih banyak digunakan untuk mempelajari nilai-nilai kehidupan itu sendiri. Seperti nilai-nilai sosial, adab, budaya, nilai-nilai ketuhanan dan lain-lain. Oleh sebab itu, Irkham dalam Gong (2012) menyebut literasi sebagai keberaksaraan.

Dengan demikian dapat dipahami bahwa literasi tidak hanya dimaknai sebagai kemampuan membaca dan menulis tekstual saja, tetapi juga harus mampu membaca kontekstualnya yang lahir dari proses sosial dan kepekaan terhadap maksud/tujuan yang terkandung didalamnya. Dalam pengertian lebih jauh, literasi juga dipahami sebagai kemampuan untuk memprediksi dampak yang ditimbulkan tekstual yang ditulisnya.

seiring perkembangan teknologi informasi dan komunikasi, pemaknaan literasi tidak saja berhubungan dengan teks, tetapi juga kemampuan membaca dan menulis dalam bentuk visual seperti gambar, foto maupun audiovisual seperti video serta berbagai bentuk hasil kerja komputerisasi. Dalam arti lain maka dapat dipahami bahwa literasi merupakan suatu tahap perilaku sosial yaitu kemampuan individu untuk membaca, menginterpretasikan, dan menganalisa informasi dan pengetahuan yang mereka dapat untuk melakukan perubahan kearah yang lebih baik.

Pengertian beriutnya adalah digitalisasi dimana menurut Kamus Besar Bahasa Indonesia (2008:231) digitalisasi diartikan sebagai suatu proses pemberian atau pemakaian sistem digital: implementasi. Dengan kata lain, digitalisasi adalah 
segala sesuatu yang prosesnya berkaitan dengan digital. Sesuai perkembangan teknologi informasi dan komunikasi, hampir seluruh aspek kegiatan manusia bersentuhan atau menggunakan teknologi digital. Jika sebelumnya untuk mengirim sebuah pesan harus dilakukan secara manual yang memakan waktu dan biaya tinggi, kini dengan kehadiran teknologi digital mengirim pesan dapat dilakukan dalam beberapa menit, bahkan detik dengan harga yang jauh lebih murah.

Dengan demikian digitalisasi telah mengubah dan melakukan transfigurasi teknologi media dan komunikasi. Jaringan telepon otomatis yang sebelumnya dioperasikan secara manual sekarang bisa dioperasikan oleh perangkat jaringintelek komputer dengan perangkat lunak yang mampu mengkonfigurasikan jaringan cerdas (intelligent network) dengan fitur-fitur kompleks digital. Digitalisasi juga mengarahkan konvergensi produk dan proses aplikasi informasi yang dapat melakukan berbagai fungsi audio-visual dan komputasi.

Konvergensi produk komunikasi terjadi ketika televisi dan komputer menjadi satu produksi media sehingga akses ke internet dapat dilakukan dari pesawat televisi (lihat layanan Indovision yang menyediakan jaringan komputer dengan band-width yang cukup lebar atau yang bisa disebut broadband channel). Sebaliknya, siaran televisi dapat dinikmati lewat internet secara real time.

Literasi Digital merupakan kemampuan dasar secara teknis untuk menjalankan komputer serta internet, yang ditambah dengan memahami serta mampu berpikir kritis dan juga melakukan evaluasi pada media digital dan bisa merancang konten komunikasi.

Menurut Paul Gilster (1997) dalam bukunya yang berjudul Digital Literacy, literasi digital diartikan sebagai kemampuan untuk memahami dan menggunakan informasi dalam berbagai bentuk dari berbagai sumber yang sangat luas yang diakses melalui piranti komputer. Bawden (2001) menawarkan pemahaman baru mengenai literasi digital yang berakar pada literasi komputer dan literasi informasi. Literasi komputer berkembang pada dekade 1980-an, ketika komputer mikro semakin luas dipergunakan, tidak saja di lingkungan bisnis, tetapi juga di masyarakat. 
Namun, literasi informasi baru menyebar luas pada dekade 1990-an manakala informasi semakin mudah disusun, diakses, disebarluaskan melalui teknologi informasi berjejaring. Dengan demikian, mengacu pada pendapat Bawden, literasi digital lebih banyak dikaitkan dengan keterampilan teknis mengakses, merangkai, memahami, dan menyebarluaskan informasi.

Sementara itu, Douglas A.J. Belshaw (2011) dalam tesisnya What is 'Digital Literacy"? mengatakan bahwa ada delapan elemen esensial untuk mengembangkan literasi digital, yaitu sebagai berikut: 1) Kultural, yaitu pemahaman ragam konteks pengguna dunia digital; 2) Kognitif, yaitu daya pikir dalam menilai konten; 3) Konstruktif, yaitu reka cipta sesuatu yang ahli dan aktual; 4) Komunikatif, yaitu memahami kinerja jejaring dan komunikasi di dunia digital; 5) Kepercayaan diri yang bertanggung jawab; 6) Kreatif, melakukan hal baru dengan cara baru; 7) Kritis dalam menyikapi konten; dan 8) Bertanggung jawab secara sosial.

Aspek kultural, menurut Belshaw, menjadi elemen terpenting karena memahami konteks pengguna akan membantu aspek kognitif dalam menilai konten. Dari beberapa pendapat di atas dapat disimpulkan bahwa literasi digital adalah pengetahuan dan kecakapan untuk menggunakan media digital, alat-alat komunikasi, atau jaringan dalam menemukan, mengevaluasi, menggunakan, membuat informasi, dan memanfaatkannya secara sehat, bijak, cerdas, cermat, tepat, dan patuh hukum dalam rangka membina komunikasi dan interaksi dalam kehidupan sehari-hari.

\section{PEMBAHASAN}

Gerakan Nasional Literasi Digital \#SiBerkreasi yang diluncurkan pada 2 Oktober 2017 oleh Menteri Komunikasi dan Informatika Rudiantara merupakan program yang fokus utamanya adalah melakukan seruan kepada masyarakat luas untuk secara aktif menyebarluaskan konten positif. Gerakan yang melibatkan berbagai institusi, baik pemerintah, swasta, beragam komunitas, hingga para pegiat media sosial ditujukan untuk mengatasi berbagai konten negatif yang secara massif beredar luas di masyarakat melalui jejaring media sosial. 
Seperti disampaikan Menteri Komunikasi dan Informatika pada peluncuran Gerakan Nasional Literasi Digital (GNLD) \#SiBerkreasi bahwa upaya pemerintah dalam melindungi masyarakat pengguna internet dari berbagai dampak negatif adalah, pertama melalui pelambatan hingga pemblokiran situs maupun akun yang memuat konten negatif. Dan kedua adalah malalui pemberdayaan masyarakat melalui kegiatan promosi dan edukasi seperti yang dilakukan dalam GNLD \#SiBerkreasi.

Sebagai gambaran GNLD Siberkreasi memiliki 4 program unggulan Siberkreasi antara lain, School of Influencer, Pandu Digital, Kreator Nongkrong, dan literasidigital.id. Dalam literasidigital.id nantinya, masyarakat diharapkan bisa mendapat pengetahuan seputar pendidikan digital, ekonomi digital, cybercrime, dan lain-lain dalam bentuk buku, video, dan infografis yang dapat diunduh secara gratis.Kemudian Program Pandu Digital.

Program tersebut merupakan program bagi masyarakat umum yang khusus pada hal community empowerment berbasis komunitas, collaborative engagement dengan menyebarluaskan pengetahuan etika digital, dan memperkuat ekonomi digital dengan roadmap e-commerce Indonesia.

Sementara itu, School of Influencer, lebih berfokus pada pengembangan konten positif di Internet dengan cara mengajak anak-anak muda Indonesia untuk memproduksi konten kreatif seperti video, gambar, artikel, blog atau vlog yang positif di Internet. Dan Kreator Nongkrong adalah komunitas bentukan Siberkreasi yang mewadahi para influencer/konten kreator untuk saling bersinergi dan tetap produktif dalam memproduksi dan menyebarkan konten positif.

Survei yang diselenggarakan Siberkreasi pada Maret-November 2019 terhadap 987 responden di 18 kota di Indonesia menunjukkan bahwa 54,4 persen responden masih bingung dalam mengidentifikasi hoaks. Dan ironisnya, kondisi tersebut tergambar dari responden yang umumnya berpendidikan tinggi, seperti mahasiswa, guru, dan aparatur sipil negara.

Dengan kata lain, maka kehadiran teknologi digital yang menawarkan berbagai kemudahan dan kecepatan dalam penyampaian informasi dan komunikasi, tidak disertai kesiapan dan kesadaran masyarakat untuk melakukan filter terhadap 
berbagai informasi yang diterima. Tidak sedikit masyarakat mudah meneruskan dan membagikan informasi yang diterima tanpa melalui proses cek and ricek trhadap kebenaran informasi tersebut. Hasilnya, informasi hoaks, berita bohong maupun berita palsu sangat mudah tersebar luas. Kondisi yang sama juga terjadi dalam distribusi konten-konten yang dinilai negatif, seperti berbau SARA, berbau kekerasan, mengandung unsur pornografi maupun provokatif sangat mudah beredar di masyarakat melalui jejaring on line.

Persoalan tidak sesederhana 'asal share' tetapi ketika berita hoaks atau berita palsu maupun berita bohong beredar luas di masyarakat dapat memicu berbagai polemik hingga konflik sosial yang jauh lebih rumit dan kompleks. Seperti yang terjadi pada kerusuhan di tanah Papua 2019 lalu, atau penyerangan terhadap Polsek Pasar Rebo dan Polsek Ciracas dipenghujung Agustus 2020 lalu yang awalnya dipicu penyebaran berita bohong atau hoaks.

Selain hoaks, berita palsu maupun berita bohong, konten bermuatan negatif bahkan kriminal juga bertebaran diinternet dan mudah diakses masyarakat berbagai golongan usia. Mulai dari pornografi, perjudian hingga penipuan on line. Akibatnya tidak hanya meresahkan masyarakat tetapi juga menimbulkan kerugian moril maupun materil yang tidak sedikit.

Sepanjang 2018 pemeritah melalui Kemenkominfo telah melakukan pemblokiran terhadap 961.456 situs yang memuat konten negatif ${ }^{14}$. Total sebanyak 106.466 situs yang mengandung konten pornografi ditutup karena adanya aduan dari masyarakat ataupun permintaan lembaga. Jumlah itu menjadikan jumlah keseluruhan situs pornografi yang telah diblokir sebanyak 883.348 situs sejak tahun 2010. Data yang dirilis trustpositif kominfo dari Januari hingga Agustus 2020 konten pornografi menduduki peringkat kedua dengan 26537 situs yang diadukan. Pelanggaran HKI menempati posisi ketiga sebanyak 2030 pengaduan. Disusul penipuan on line sebaanyak 1449, dan situs judi on line menempati urutan pertama konten yang diadukan masyarakat.

\footnotetext{
${ }^{14}$ https://nasional.kompas.com/read/2018/12/22/09371731/sepanjang-2018-pemerintahblokir-hampir-1-juta-situs-berkonten-negatif.
} 
Gerakan Nasional Literasi Digital merupakan upaya pemerintah dalam memberikan layanan keamanan bagi masyarakat dalam menjalankan aktifitasnya di dunia digital. Melalui pendekatan membatasi hingga memblokir situs-situs bermuatan negatif berdasarkan aduan maupun temuan TIM AIS Kominfo yang rutin berpatroli selama 24 jam sehari, tujuh hari dalam sepekan diharapkan masyarakat terbantu dan terlindungi dari berbagai bentuk informasi negatif maupun kejahatan di dunia maya.

Selain itu pemerintah juga berupaya melakukan klarifikasi maupun publikasi terhadap penyebaran berita hoaks, berita palsu maupun berita bohong. Kendati dalam pelaksanaannya peredaran hoaks, berita bohong maupun berita palsu lebih massif dan agresif menyasar masyarakat pengguna media sosial.

Disisi lain, Gerakan Nasional Literasi Digital juga menitikberatkan pada upaya edukasi dan pemberdayaan bagi masyarakat. Melalui kegiatan promosi dan publikasi diharapkan masyarakat dapat lebih termotivasi dalam memproduksi konten-konten positif untuk melawan massifnya konten negatif.

Dari gambaran diatas terlihat bahwa Gerakan Nasional Literasi Digital merupakan upaya pemerintah untuk memberikan layanan keamanan kepada masyaraka sekaligus meningkatkan keberdayaan masyarakat dalam menyikapi perkembangan dunia digital melalui literasi digital.

Kendati Gerakan Nasional Literasi Digital memberikan manfaat bagi sebagian masyarakat, namun pada kenyataannya tidak sedikit yang memandang program ini lebih merupakan upaya pemerintah untuk membatasi masyarakat dalam memperoleh informasi maupun berkreasi di dunia maya.

Seperti disebutkan diatas upaya pemblokiran berbagai situs berkonten negatif terus dilakukan oleh Kemenkominfo. Tidak hanya berdasarkan laporan atau aduan, tetapi juga melakukan ppatroli siber selama 24 jam sehari, tuju hari dalam sepekan. Pendek kata, pemerintah terus mengawasi aktivitas di dunia maya. Persoalan muncul ketika pada kenyataannya upaya pemblokiran juga merambah ke situs maupun akun-akun yang berbau politik maupun kontra terhadap pemerintahan. Bahkan tidak sedikit pemilik akun harus berurusan dengan hukum ketika menyuarakan pendapatnya yang tidak sejalan dengan rezim penguasa. 
Berdasarkan laporan tahunan SAFENet (2018), lembaga nirlaba yang bergerak dibidang advokasi kebebasan berekspresi diinternet, pada 2018 terdapat 25 kasus pemidanaan dengan menggunakan pasal UU ITE. Jumlah ini menurun dari 2017 yang mencapai 53 kasus. Sementara jumlah kasus berdasarkan profesi yang diadukan terjadi peningkatan yang signifikan terhadap kalangan jurnalis atau media. Pada 2018, total kasus yang melibatkan jurnalis atau media mencapai 8 kasus, naik lebih dari dua kali lipat dari tahun 2017 dengan tiga kasus. Di posisi kedua adalah masyarakat umum/warganet sebanyak 4 kasus, Aparatur sipil berada di urutan ketiga dengan tiga korban. UU ITE juga menjerat tenaga pendidik (2 kasus) serta aktivis dan mahasiswa masing-masing satu kasus.

Pada 2017, korban terbanyak berasal dari kalangan warga biasa yakni 30 kasus. Disusul aktivis (4 kasus), entertainer (3 kasus), serta jurnalis dan tenaga pendidik masing-masing 2 kasus. Pejabat publik tetap menjadi kelompok dominan sebagai pelaku pemidanaan. Pada 2018, terdapat 11 kasus yang dilaporkan oleh pejabat publik seperti kepala daerah atau kepala instansi/departemen. Selain pejabat publik, terdapat 6 kasus UU ITE yang dilaporkan oleh kelompok profesional seperti pengacara dan dokter.

Selain itu, peningkatan pelaporan juga terjadi pada terlapor yang berprofesi sebagai pejabat publik, dari total dua kasus pada 2017 menjadi tiga kasus pada 2018. Sementara itu, jumlah pelaporan untuk terlapor dengan profesi sebagai aktivis, artis atau penulis, kalangan profesi, pekerja swasta, dan warga masingmasing mengalami penurunan.

Berdasarkan pasal hukum yang dituduhkan, kriminalisai pengguna Internet pada tahun 2018 paling banyak menggunakan pasal defamasi atau pencemaran nama baik, yakni pasal 27 ayat 3 Undang-undang Informasi dan Transaksi Elektronik (ITE) sebanyak 16 pelaporan, disusul oleh pasal kebencian (pasal 28 ayat 2) sebanyak lima pelaporan. Sedangkan untuk tuduhan defamasi sekaligus kebencian, pasal pengancaman, dan pasal pornografi tercatat masing-masing sebanyak satu laporan.

Sedangkan profesi pelapor, didominasi kalangan pejabat publik, sebanyak 13 pelaporan pada 2017 dan 14 pelaporan pada 2018. Sementara kalangan awam 
jumlah pelaporannya menurun dari 11 pelaporan pada 2017 menjadi 3 pelaporan pada 2018, dan jumlah pelapor dari kalangan profesi merosot menjadi 7 pelaporan dibandingkan tahun sebelumnya mencapai 26 pelaporan.

Data yang didokumentasikan SAFEnet berbeda jauh dengan putusan Mahkamah Agung trhadap pidana khusus pelanggaran ITE yang mengalami peningkatan sejak 2014 hingga 2018. Dalam direktori putusan MA, terdapat 292 putusan pidana khusus ITE, jumlah jni naik dua kali lipat dibanding 2017 sebanyak 140 kasus. Dan total hingga Agustus 2020 terdapat 1473 putusan terhadap pelanggaran UU ITE.

Jika dilihat dari pasal pemidanaan yang digunakan mayoritas pasal penghinaan dan pencemaran nama baik atau defamasi. Dari sebanyak 276 kasus pada 2018 sebanyak 45\% putusan menggunakan pasal 27 ayat 3 yang berbunyi: "dengan sengaja dan tanpa hak mendistribusikan dan/atau mentransmisikan dan/atau membuat dapat diaksesnya Informasi Elektronik dan/atau Dokumen Elektronik yang memiliki muatan penghinaan dan/atau pencemaran nama baik".

Selain itu kasus ujaran kebencian atau pasal 28 ayat 2 UU ITE dan atau juncto Pasal 45A ayat 2 sebanyak 22\% dan melanggar kesusilaan sebanyak 14\% (Pasal 27 ayat 1). Pasal 45A ayat 2 yang berbunyi: "dengan sengaja dan tanpa hak menyebarkan informasi yang ditujukan untuk menimbulkan rasa kebencian atau permusuhan individu dan masyarakat tertentu berdasarkan atas suku, agama, ras dan antar golongan (SARA)",

Berdasarkan catatan tersebut jelas bahwa kebebasan menyuarakan pendapat dan berekspresi di Indonesia masih sangat dibatasi bahkan cenderung dihantui pemidanaan oleh para penguasa. Tentu dalam kontek penyelenggaraan $e$ government sebagai upaya mewujudkan good government upaya ini menjadi kontraproduktif terhadap upaya pemberdayaan masyarakat. Melalui upaya-upaya penerapan hukum dan pemidanaan terhadap warganet atau netizen yang berbeda pandangan dengan penguasa merupakan sebuah bentuk tirani dan pengkerdilan nilai-nilai demokrasi.

Disisi lain, warganet yang tidak sepaham terlebih mengkritik kebijakan penguasa seringkali mengalami perundungan, penghinaan bahkan dipermalukan 
oleh warganet yang pro terhadap penguasa. Perbedaan pandangan politik seringkali dipertontonkan bukan sebagai dialektika intelektual tetapi lebih pada pertunjukan emosional dan arogansi.

Dalam konteks tersebut apakah GNLD yang salah satu programnya adalah melatih dan membina para influencer untuk menyebarkan informasi positif, juga ikut terlibat atau dilibatkan untuk 'menyerang' suara-suara sumbang yang mengkrutik penguasa? Untuk membuktikan ini perlu investigasi lebih jauh untuk melacak jejak digitalnya. Namun setidaknya pernyataan Direktur Eksekutif Lokataru Haris Azhar yang menuding pemerintah membayar buzzer atau inluencer untuk menggiring opini publik. Bahkan para buzzer juga 'menyerang' warga yang mengkritik pemerintah di media sosial ${ }^{15}$ patut diperhatikan. Terlebih pemerintah juga menyediakan anggaran puluhan milyar untuk membayar jasa para influencer untuk membantu pemerintah menyampaikan berbagai informasi positif. ${ }^{16}$

Selain persoalan keberadaan influencer yang dikelola pemerintah melalui GNLD hal mendasar yang patut dipertanyakan dan perlu dijelaskan adalah makna 'informasi positif' yang harus disebarluaskan para influencer ini. Apakah yang dimaksud informasi positif adalah informasi yang lurus dan pro terhadap pemerintah? Sementara yang kontra dan mengkritik pemerintah atau penguasa dipandang sebagai informasi negatif? Jika melihat trend-nya, narasi 'informasi positif’ lebih merujuk pada para influencer ini sebagai corong pemerintah sekaligus 'watchdog' yang siap menyalak ketika tuannya diganggu.

Jika kondisi tersebut yang terjadi maka dalam konteks good governance, keberadaan GNLD jauh dari nilai-nilai pemberdayaan masyarakat. Pun halnya interaksi yang dibangun melalui gerakan ini tidak terdapat nilai kesetaraan, tetapi lebih pada hubungan patron-clien yang merupakan salah satu hambatan penting dalam pembangunan demokrasi maupun penyelenggaraan pemerintahan yang baik.

Untuk melihat GNLD dari perspektif good governance, maka perlu dikaji apakah gerakan ini telah memenuhi tiga pilar penting dalam pelaksanaan good

\footnotetext{
${ }^{15}$ https://www.suara.com/news/2020/06/20/162716/pemerintah-dituding-hamburkan-uang-pajakrakyat-untuk-bayar-buzzer, diakses 2 September 2020

${ }^{16} \mathrm{https} / / /$ cirebon.pikiran-rakyat.com/nasional/pr-04714641/istana-negara-dituding-kelola-buzzerstaf-pemerintah-gunakan-influencer-tapi-untuk-tujuan-positif, diakses 2 September 2020
} 
governance yang menurut Mardiasmo (2009:18) terdapat tiga pilar yang saling berkaitan untuk mewujudkan good governance yaitu transparansi, partisipasi, dan akuntabilitas, serta terdapat satu elemen lagi yang dapat mewujudkan good governance yaitu value for money (ekonomi, efisiensi, dan efektivitas).

\section{A. Transparansi}

Gerakan Nasional Literasi Digital sebagai gerakan pemberdayaan masyarakat untuk melawan berita hoaks, berita bohong, berita palsu dan berbagai konten negatif dengan cara memperbanyak konten-konten positif tampaknya tidak bisa menunjukan transparansi dalam tata kelolanya. Seperti misalkan dalam tata kelola keuangan gerakan ini masih kurang terbuka dan sulit diakses oleh publik. Selain persoalan tata kelola keuangan, adanya ketidakjelasan dalam definisi konten positif maupun konten negatif juga menunjukan ketidaktransparanan program ini. Dengan kata lain, tidak adanya standar yang jelas, tegas dan terbuka maka penentuan suatu konten mengandung unsur negatif maupun positif menjadi domain salah satu pihak. Hal ini terbukti ketika pemerintah melakukan berbagai uoaya pemblokiran terhadap situs maupun akun-akun yang bernada kritik terhadap pemerintah. Dalam artian lain, terjadi monopoli dalam proses pengambilan keputusan untuk menentukan layak atau tidak sebuah konten atau akun mempublikasikan informasi dan berkreasi di dunia maya. Dan ironisnya, keberadaan influencer untuk menyebarkan berita positif kepada masyarakat lebih tampak sebagai upaya menggiring opini masyarakat agar tidak kritis terhadap pemerintah. Dan jika ada yang kritis maka seringkali mendapat bullying, penghinaan hingga berbagai bentuk intimidasi di dunia maya, apakah pihak-pihak yang melakukan ini adalah para influencer yang tergabung dalam GNLD perlu dilakukan kajian lebih jauh melalui pendekatan digital forensik.

\section{B. Partisipasi}

GNLD Siberkreasi dalam kampanyenya berupaya merangkul semua pihak. Berdasarkan catatan Siberkreasi, gerakan ini menghimpun setidaknya 108 yang terdiri dari berbagai lembaga, komunitas maupun mayarakat penggiat internet. Dari 
konteks ini, gerakan ini tampaknya membuka ruang partisipasi publik yang seluasluasnya. Namun yang menjadi persoalan sejauh mana masyarakat dapat menyalurkan aspirasinya melalui ruang partisipasi tersebut.

Dalam pengertian lain, partisipasi dapat menjadi bermakna demokrasi jika didalamnya terdapat ruang penyampaian aspirasi dan adanya ruang interaksi untuk melakukan negosiasi terhadap berbagai kepentingan. Sebaliknya, jika partisipasi dibangun tanpa ada ruang aspirasi dalam menyampaikan pendapat dan meraih posisi tawar yang layak, maka partisipasi tersebut lebih bermakna menghimpun atau mengumpulkan kelompok-kelompok masyarakat yang memiliki pandangan dan minat yang sama. Oleh karenanya, konten yang dihasilkan dari gerakan ini cenderung seragam, menyuarakan hal yang sama. Seperti yang disampaikan Juru bicara presiden Fadjroel Rachman yang menyebut influencer termasuk aktor digital memiliki peran penting dalam menyampaikan komunikasi kebijakan publik. "Oleh karenanya, dalam era masyarakat digital, para aktor digital yang merupakan key opinion leader di banyak negara demokrasi ini, sangat aktif mengambil peran penting dalam komunikasi kebijakan publik," katanya. ${ }^{17}$

Dengan kata lain, sebagai aktor digital penting influencer dapat menentukan apakah perkembangan digital akan dioptimalkan untuk membangun demokrasi di masyarakat atau justru akan diarahkan sebagai legitimasi pemerintah yang itu artinya Digital Authoritarianism menjadi sebuah keniscayaan melalui gerakan ini.

\section{Akuntabilitas}

Sebuah rezim dapat disebut good governance jika kebijakan yang dikeluarkannya dapat dipertanggungjawabkan kepada publik. Dalam konteks ini, GNLD sebagai sebuah program pemerintah untuk mengedukasi masyarakat di era digital tampaknya akan sulit terwujud. Kondisi program yang minim akses masyarakat menyulitkan proses kontrol terhadap gerakan ini.

Kurang terbukanya pemerintah terhadap program ini menimbulkan berbagai spekulasi bahkan kecutigaan yang mengarah pada tudingan bahwa gerakan ini

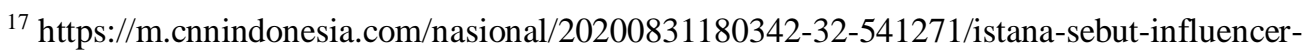
ujung-tombak-demokrasi-digital
} 
merupakan upaya pemerintah untuk melindungi kepentingannya dengan memanfaatkan masyarakat untuk membangun opini seluas-luasnya melalui jejaring sosial yang dimiliki para influencer yang tergabung didalamnya.

Kendati sekolah influencer yang merupakan salah satu program GNLD terbuka untuk masyarakat luas, namun hingga kini tidak ada kejelasan bagaimana gerakan ini bekerja dan bagaimana hasil yang inhin diraih. Sehingga masyarakat tidak bisa mengontrol dan melakukan pengawasan terhadao kebijakan ini.

Dari parametr-parameter trsebut maka GNLD Siberkreasi dari kaca mata good governace merupakan kebijakan yang sulit untuk bisa dipertanggungjawabkan kepada publik. Kendati gerakan ini terbuka dan aktif melakukan sosialisasi namun kurang terbukanya gerakan ini memunculkan berbagai persepsi dari dugaan terhadap gerakan ini.

\section{KESIMPULAN}

Gerakan Nasional Literasi Digital sebagai bagian dari proses pemberdayaan masyarakat merupakan program yang positif untuk membantu warganet melalui fase transformasi dari dunia analog/manual ke dunia digital. Adanya 'gagap digital' yang ditandai fenomena 'asal bagi' hingga merebaknya aksi bulying, penghinaan, persekusi dan mendarah daging menjadi budaya kebencian perlu segera diantisipasi dengan meningkatkan kesadaran dan memberdayakan warganet dalam berinteraksi di dunia maya.

Upaya GNLD untuk melawan konten negatif dengan memperbanyak postingan berisi informasi positif tidak akan menunjukan hasil maksimal jika gerakan ini hanya menjadi monopoli, bahkan 'alat penguasa' untuk menghadapi sikap kritis tterhadap masyarakat. Dalam arti lain, gerakan ini harus terbuka dan melibatkan masyarakat seluas-luasnya sehingga terjadi pemerataan dalam proses literasi digital. Ini yang pertama.

Kedua, GNLD harus menjadi gerakan masyarakat dengan meminimalisir campur tangan pemerintah. Sesuaai fungsinya pemerintah hanya sebagai regulator yang menyediakan perangkat hukum dan aturan main yang dalam penyusunannya 
melibatkan pihak-pihak terkait. Dengan demikian GNLD dapat lebih independen dan tidak dituding sebagai gerakan pemerintah untuk menyerang para pengkritik.

Dan ketiga yang tak kalah pentingnya adalah perlu kejelasan trhadap makna konten positif yang menjadi tujuan gerakan ini. Perlu definisi yang jelas dan tegas yang dirumuskan bersama antara pemerintah dengan pihak-pihak berkepentingan. Dengan adanya kejelasan terhadap definisi konten positif dapat lebih melindungi daya kritis masyarakat terhadap pemerintah dan menghargai perbedaan sebagai sebuah proses demokrasi.

Perlunya perlindungan terhadap perbedaan, toleransi dan sikap kritis masyarakat di dunia maya harus menjadi bagian integral dari Gerakan Nasional Literasi Digital. Sebab bagaimanapun, upaya kontrol yang berlebih dari pemerintah, terlebih menggunakan sebagian masyarakat untuk menekan masyarakat lain yang kritis terhadap pemerintah merupakan gejala otoriter. Dan gejala tersebut telah dilaporkan dari hasil temuan Freedom House on the Net 2018 yang menyimpulkan bahwa terdapat gejala Digital Authoritarianism yang tidak hanya terjadi di Indonesia, tapi juga di seluruh dunia. Kondisi ini dibuktikan dengan upaya berbagai Pemerintah di seluruh dunia dalam memperketat kontrol atas data publik dan menggunakan klaim "berita palsu" untuk menekan perbedaan pendapat menurun dalam tahun kedelapan berturut-turut sejak $2010^{18}$

\section{DAFTAR PUSTAKA}

Ali Romdhoni, 2013. Al-Qur'an dan Literasi. Depok: Literatur Nusantara

Atmoko, Pitoyo Widhi. 2015. Digitalisasi dan Alih Media. Malang: Universitas Bramelati.

Belshaw, D. A.J. (2011). What is digital literacy? A Pragmatic investigation, thesis. United Kingdom

Departemen Pendidikan Nasional, Kamus Besar Bahasa Indonesia Pusat Bahasa, 2008. Jakarta., Gramedia Pustaka Utama.

Donald, M. 1991. Origins of the modern mind: three stages in the evolution of culture and cognition. Cambridge MA: Harvard University Press

\footnotetext{
${ }^{18}$ https://freedomhouse.org/report/freedom-net/freedom-net-2018
} 
Eko Indrajit, Richardus. (2002). Buku Pintar Linux : Membangun Aplikasi eGovernment. Jakarta :PT Elex Media Komputindo.

Eko Indrajit, Ricardus dkk. 2005. E Government in Action. Yogyakarta: Penerbit Andi

Eko Indrajit, Richardus. 2006. Electronic Government "Strategi Pembangunan Sistem Pelayanan Publik Berbasis Teknologi Digital”. Yogyakarta, Andi.

Gilster, P. 1997. Digital literacy, New York: Wiley.

Iriantara, Yosal. 2009. Literasi Media: Apa, Mengapa, dan Bagaimana,. Bandung, Simbiosa Rekatama Media

John Creswell, Research Design, Qualitative, Quantitative, and Mixed Method Approaches, (California: SAGE Publications, 2014), hal.20

J. R. Raco, Metode Penelitian Kualitatif: Jenis, Karakteristik, dan Keunggulannya, (Jakarta: PT Gramedia Widiasarana Indonesia, 2010). Hal. 82-84

Kern, Richard (2000). Literacy \& Language Teaching. Oxford : Oxford University Press

Laporan Tahunan SAFEnet 2018, Jalan Terjal Memperjuangkan Hak-hak Digital

Lexy Moleong, 2011, Metodologi Penelitian Kualitatif. Bandung: Remaja Rosdakarya.

Rianto, budi dkk. 2012. Polri dan Aplikasi E-Government dalam pelayanan Publik. Surabaya. Putra Media Nusantara

Stuart D. Lee. 2001. Digital Imaging: a practical handbook. Londong: Facet Publising.

Wahab, Abdul. (1990) Pengantar Analisis Kebijakan Negara. Jakarta, Rineka Cipta.

Wibawa, Samodera. 2009. Administrasi Negara Isu-Isu Kontemporer. Yogyakarta: Graha Ilmu

\section{Internet}

https://time.com/4457110/internet-trolls/, diakses pada 28 Agustus 2020

https://tirto.id/bullying-dan-penindasan-di-media-sosial-bVZj, diakses 27 Agustus 2020 
https://radarsukabumi.com/berita-utama/youtuber-ferdian-paleka-bikin-ulah-kewaria-rumahnya-dikepung-warga/, diakses pada 28 Agustus 2020

https://m.detik.com/news/berita/d-5152474/pernyataan-lengkap-panglima-tniterkait-hoax-picu-perusakan-polsek-ciracas, diakses tanggal 31 Agustus 2020

https://megapolitan.kompas.com/read/2020/08/29/21490211/perusakan-polsekciracas-dipicu-kabar-bohong-yang-disebar-oknum-anggota, diakses 31 Agustus 2020

https://www.jawapos.com/nasional/28/12/2019/kaleidoskop-2019-karena-beritahoax-kerusuhan-wamena-pecah/, diakses 30 Agustus 2020

https://m.cnnindonesia.com/teknologi/20190819203042-185-422838/kominfoungkap-temuan-hoaks-saat-rusuh-papua, diakses 30 Agustus 2020

https://sains.kompas.com/read/2019/09/24/170300323/kerusuhan-wamena-

kenapa-kemarahan-karena-hoaks-bisa-sangat-merusak-?page=all, $\quad$ diakses 30 Agustus 2020

https://katadata.co.id/safrezifitra/digital/5e9a5512bcbb0/kementerian-kominfoidentifikasi-453-hoaks-sepanjang-maret-2019, diakses pada 30 Agustus 2020

https://nasional.kompas.com/read/2018/12/22/09371731/sepanjang-2018 pemerintah- blokir-hampir-1-juta-situs-berkonten-negatif.

https://www.suara.com/news/2020/06/20/162716/pemerintah-ditudinghamburkan-uang-pajak-rakyat-untuk-bayar-buzzer, diakses 2 September 2020 https://cirebon.pikiran-rakyat.com/nasional/pr-04714641/istana-negara-ditudingkelola-buzzer-staf-pemerintah-gunakan-influencer-tapi-untuk-tujuan-positif, diakses 2 September 2020

https://freedomhouse.org/report/freedom-net/freedom-net-2018 Goody, J. \& Watt, I. 1963. The consequences of literacy. Contemporary Studies in Society and History http://www.proquest/umi/pqd.web Diunduh pada 30 Agustus 2020 https://m.cnnindonesia.com/nasional/20200831180342-32-541271/istana-sebutinfluencer-ujung-tombak-demokrasi-digital 